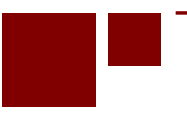

C E N T E R for RETIREMENT RE S E A R C H at BOSTON COLLEGE

\title{
WOULD GREATER AWARENESS OF SOCIAL SECURITY SURVIVOR BENEFITS AFFECT CLAIMING DECISIONS?
}

\author{
Anek Belbase and Laura D. Quinby
}

CRR WP 2018-12

October 2018

\author{
Center for Retirement Research at Boston College \\ Hovey House \\ 140 Commonwealth Avenue \\ Chestnut Hill, MA 02467
}

Tel: 617-552-1762 Fax: 617-552-0191

http://crr.bc.edu

Both authors are with the Center for Retirement Research at Boston College. Anek Belbase is a research fellow and Laura D. Quinby is a research economist. The research reported herein was performed pursuant to a grant from the U.S. Social Security Administration (SSA) funded as part of the Retirement Research Consortium. The opinions and conclusions expressed are solely those of the authors and do not represent the opinions or policy of SSA, any agency of the federal government, or Boston College. Neither the United States Government nor any agency thereof, nor any of their employees, makes any warranty, express or implied, or assumes any legal liability or responsibility for the accuracy, completeness, or usefulness of the contents of this report. Reference herein to any specific commercial product, process or service by trade name, trademark, manufacturer, or otherwise does not necessarily constitute or imply endorsement, recommendation or favoring by the United States Government or any agency thereof. The authors thank Abigail Walters for excellent research assistance.

(C) 2018, Anek Belbase and Laura D. Quinby. All rights reserved. Short sections of text, not to exceed two paragraphs, may be quoted without explicit permission provided that full credit, including (C) notice, is given to the source. 


\begin{abstract}
About the Center for Retirement Research
The Center for Retirement Research at Boston College, part of a consortium that includes parallel centers at the University of Michigan and the National Bureau of Economic Research, was established in 1998 through a grant from the Social Security Administration. The Center's mission is to produce first-class research and forge a strong link between the academic community and decision-makers in the public and private sectors around an issue of critical importance to the nation's future. To achieve this mission, the Center sponsors a wide variety of research projects, transmits new findings to a broad audience, trains new scholars, and broadens access to valuable data sources.
\end{abstract}

Center for Retirement Research at Boston College

Hovey House

140 Commonwealth Ave

Chestnut Hill, MA 02467

Tel: 617-552-1762 Fax: 617-552-0191

http://crr.bc.edu

Affiliated Institutions:

The Brookings Institution

Syracuse University

Urban Institute 


\begin{abstract}
Most Americans enter retirement as married couples, and one spouse, typically the wife, outlives the other. Many widows lack the income needed to maintain the standard of living they had when their husbands were alive. Widows would generally have more adequate incomes if their husbands, who are typically the higher earner in the couple, delayed claiming Social Security. This project uses the Health and Retirement Study (HRS) to test the extent to which husbands consider their wives' well-being as widows when making claiming decisions. It then uses an online experiment to determine whether raising a husband's awareness of the risks that his widow faces, and how delayed claiming can reduce those risks, affect his claiming behavior.
\end{abstract}

The paper found that:

- Husbands do not seem to consider the prospective drop in income experienced by their widows when choosing a Social Security claiming age.

- Husbands respond instead to immediate concerns such as pension incentives and health conditions.

- A simple information intervention that highlights the likelihood and consequences of widowhood, and demonstrates how delayed claiming enhances survivor benefits, may be insufficient to change the stated claiming intentions of older husbands.

- The framing of these information interventions (e.g., presenting the full retirement age as the default) seems to affect claiming at least as much as the content presented.

The policy implications of the findings are:

- Informing husbands that they can improve their widows' financial well-being by claiming later may be ineffective in alleviating widows' poverty.

- An alternate approach would develop policies to protect widows that at least partially decouple survivor benefits from the husband's claiming age.

- For example, one common proposal would set survivor benefits at 75 percent of the couple's combined Social Security benefit, funded by a reduction in spousal benefits while the husband is still living. 


\section{Introduction}

Most married women will be widowed. When that happens, many will experience a drop in income well below what they will need to maintain their standard of living. Most husbands can significantly raise their future widows' incomes by delaying claiming Social Security, as survivors generally get the larger of the couple's two benefits. Since husbands typically have the larger benefit, each year he delays could raise his widow's benefit by about 7.3 percent. Given the potential for delayed claiming to alleviate widows' poverty, this paper asks two related questions: 1) does a wife's projected well-being as a widow affect the claiming decision of her husband; and 2) does informing husbands of the risks widows face and the benefits of delay raise their planned claiming ages?

The first phase of the analysis relies on the Health and Retirement Study (HRS), a longitudinal survey of older Americans that is linked to the U.S. Social Security Administration's (SSA) lifetime earnings records to provide accurate information on households' Social Security benefits. Regression analysis examines whether husbands claim later when their wives are vulnerable to large drops in pension and Social Security income after widowhood, controlling for other financial and demographic characteristics that could be correlated with both the widow's vulnerability and the husband's claiming age. Consistent with the findings of related research - notably Henriques (2018) - the HRS analysis does not uncover a statistically significant relationship between the widow's projected drop in income and her husband's claiming age. Husbands appear to make claiming decisions based on more immediate considerations, such as the retirement incentives in workforce pension plans and health status.

The second phase of the analysis uses an online experiment to determine whether raising a husband's awareness that delayed claiming could improve his wife's well-being as a widow affects his stated claiming intentions. The experiment builds on recent work by Diebold and Camilleri (2018) who modified an online version of the Social Security Statement to teach husbands ages 30-61 how their widow's survivor benefit would rise if they delayed claiming. This study focuses on a larger sample of older husbands (ages 45-62), and develops communication interventions that the SSA could easily incorporate into its online information portal: mySocialSecurity. The communications tested in this experiment are designed to be shown either on the same screen as the mySocialSecurity homepage or on a stand-alone page. 
Participants in the experiment provide basic information about their work histories so that the online survey can estimate their prospective Social Security benefits. Participants are then randomly assigned to one of three groups. Control group members see a webpage very similar to the current mySocialSecurity homepage, which provides an estimate of the worker's Social Security benefit if it is claimed at the full retirement age (FRA), with a link to an online version of the paper Social Security Statement where participants view benefit estimates at different claiming ages. Participants in the first treated group see the mySocialSecurity homepage, as well as information about the risk of poverty in widowhood, a brief explanation of the survivor's benefit, and benefit estimates for both self and survivor at three claiming ages (age 62, FRA, and age 70). Participants in the second treated group do not see the mySocialSecurity homepage; instead they receive only the brief explanation of the survivor's benefit, are informed about the risk of poverty in widowhood, and are shown estimated benefits for self and survivor at various claiming ages.

Unlike Diebold and Camilleri (2018), the information treatments delivered in this experiment do not cause husbands to increase their intended claiming ages. Instead, participants seem to respond to the framing of the mySocialSecurity homepage, which presents the viewer's FRA as the default claiming age and could be viewed as a recommendation on the part of the SSA. This conclusion is consistent with an influential study that shows how information framing affects workers' claiming decisions (Brown, Kapteyn, and Mitchell, 2013). Considered together with the HRS analysis, the online experiment also suggests that informing husbands about survivor benefits may be an ineffective way to improve widows' well-being.

The remainder of this paper proceeds as follows. The next section summarizes existing research on the financial well-being of widows and the potential for an information intervention to induce husbands to claim later. The third section introduces the HRS analysis and presents results from that exercise. The fourth section describes the online experiment and discusses the findings. The last section concludes by integrating the lessons from the descriptive and experimental analyses.

\section{Literature Review}

It is well-known that widows are much more likely to be living in poverty than married women, despite some recent improvement in their poverty rates (Mutchler et al. 2017; Smeeding 
and Sandstrom 2004; Zick and Holden 2000). Some of the difference in resources is due to the negative correlation between socioeconomic status and male mortality (Sevak et al. 2004). Yet, although poor widows might have always been poor, several studies document that the average married household experiences a 40-percent decline in income after the husband's death, with minority households faring worse than their white counterparts (Angel et al. 2007; and Gillen and Kim 2009). ${ }^{1}$ This drop in income is largely attributed to the loss of the husband's Social Security and pension benefits, combined with an increase in out-of-pocket medical expenditures (Gillen and Kim 2009; McGarry and Schoeni 2005; Weaver 2010; and Zick et al. 2004).

Consequently, married women whose households are most reliant on Social Security income are the most vulnerable to poverty in widowhood.

In a recent study, Diebold, Moulton, and Scott (2017) show that widows are 6.2 percentage points less likely to fall into poverty if their husbands delay claiming from 62 to 63, and the effect is stronger for widows most reliant on Social Security. Yet, most husbands do not appear to consider survivor benefits when making claiming decisions. Most workers claim Social Security as soon as they are eligible at age 62, reporting that they need the liquidity and that they want to retire while still healthy enough to enjoy leisure time (Brown and Perron 2011). Sass et al. (2007) find no association between claiming age and caddishness, which they define as a propensity to make financial decisions independently. Even more convincingly, Henriques (2018) shows that husbands do adjust their claiming ages to maximize the present value of their own worker benefits, but do not maximize the present value of the couple's joint benefits.

A lack of knowledge about survivor benefits could contribute to the decision to claim early. A number of surveys report high rates of ignorance about key features of Social Security survivor benefits, including the fact that a husband's actuarial penalty for claiming early carries over to his widow's survivor benefit (Brown and Perron 2011; Greenwald et al. 2010; Liebman and Luttmer 2012; and Diebold and Camilleri 2018). Similarly, Sass et al. (2007) cautiously interpret the positive relationship between educational attainment and claiming age as evidence that husbands with higher financial literacy improve the well-being of their widows. ${ }^{2}$

\footnotetext{
${ }^{1}$ Hungerford (2001) reports that the median widow experiences a 16-percent decline in income.

2 The authors are careful to point out, however, that financial education is not always effective in changing behavior, and they advocate for other policies to enhance widows' Social Security benefits.
} 
In response to these calls for financial education, Diebold and Camilleri (2018) use an online experiment to test whether information about survivor benefits increases the anticipated claiming ages of husbands ages 30-61. This experiment provides the treated husbands with extensive explanations about how delayed claiming affects individual, spousal, and survivor benefits within the framework of the Social Security Statement, an informational packet that the SSA mails to workers not yet receiving benefits. The Social Security Statement is a natural outlet for communications about benefit design because past studies have shown that it succeeds at improving knowledge, although it seems to have little effect on actual behavior (Biggs 2010; Mastrobuoni 2011; Smith and Couch 2014). Consistent with these earlier studies, Diebold and Camilleri (2018) find that information about benefit design increases planned claiming ages by about one year, but that the effect disappears in a follow-up survey three months later. The treatment effect could dissipate because respondents - married men ages 30 to 61 - are too far away from retirement to seriously contemplate widowhood. Or, husbands do not fully appreciate the financial consequences of widowhood, and so did not commit the information about survivor benefits to long-term memory. ${ }^{3}$

This study builds on the existing literature by combining a descriptive analysis of husbands' claiming behavior with an online experiment. The descriptive analysis follows the spirit of Henriques (2018), but asks whether husbands claim later when their widows are projected to experience a large drop in pension and Social Security income after the husband's death. The online experiment builds on Diebold and Camilleri (2018) in several ways. First, it informs a larger $(n=1,093)$ sample of husbands closer to retirement (ages 45-62) of the risks that widows face and how delayed claiming can improve their wives' prospects if widowed. Second, it develops web-based communication interventions that the SSA could easily adopt. Importantly, the base case in the online experiment shows respondents a webpage similar to Social Security's online benefit projection (mySocialSecurity), rather than an online version of the paper Social Security Statement. The communication interventions explored in this study are designed to be shown online either on the same screen as the mySocialSecurity homepage or on a stand-alone page.

\footnotetext{
${ }^{3}$ The intervention in Diebold and Camilleri (2018) did not provide information about the likelihood and typical length of widowhood or about the widow's typical income shortfall.
} 


\section{Do Husbands Whose Widows Would Benefit Most Claim Later?}

This section of the analysis uses the 1992-2014 waves of the Health and Retirement Study (HRS) to test whether husbands claim later when their wives are projected to experience large drops in Social Security income after widowhood. The HRS is a longitudinal dataset that surveys people ages 50 or older every two years about their labor market outcomes, savings, pension income, and public benefit receipt, among other relevant characteristics. The public-use HRS is linked to the SSA's administrative earnings records to provide accurate information on individuals' earnings histories and potential Social Security income.

The goal of this analysis is to model the claiming decision of husbands who could either choose to claim early, at age 62 , or delay until age 70 in order to promote the prospective wellbeing of their widows. To this end, the sample focuses on married men born between 1931 and 1943 to ensure that the husbands are observed in the HRS at two points in time: 1) at age 62 when they make the initial decision to claim early or delay; and, 2) at age 70 when the full benefits to claiming later are realized. ${ }^{4}$ The sample drops husbands who claim disability benefits before age 62 , since they are unlikely to be able to delay claiming, as well as husbands who do not qualify for Social Security benefits due to insufficient lifetime earnings. The sample also makes a few restrictions based on wives' characteristics. Namely, that the wife is not expected to die before the husband, based on standard mortality tables, and that the wife turns age 62 before her husband's expected year of death, so that she is likely to be out of the labor market when she becomes widowed. ${ }^{5}$ Lastly, the sample is limited to husbands whose administrative earnings histories and those of their wives are shared with the HRS, and is limited to husbands whose claiming ages are observed. ${ }^{6}$ Table 1 documents how this sample selection ultimately yields 1,867 husbands who turn age 62 between 1992 and 2006.

\footnotetext{
${ }^{4}$ Admitting younger men to the sample would bias the estimation since only those who claim early would enter the regression. Men who leave the HRS before age 70, due to death or attrition, remain in the sample if their claiming ages are observed.

${ }^{5}$ Throughout the analysis, life expectancy is calculated from 2017 cohort mortality tables provided by the Social Security Office of the Chief Actuary. Life expectancy calculations vary depending on current age, birth cohort, and sex.

${ }^{6}$ The husband's claiming age is determined from the Social Security-linked administrative records. Although this analysis augments the administrative data with self-reported claiming ages from the public-use data, about 10 percent of husbands still have missing values. For this reason, the analysis will test the sensitivity of the results to different assumptions about the value of missing claim ages.
} 


\section{Methodology}

The key variable in the HRS analysis is Drop, which captures the vulnerability of the widow if both spouses claim at 62. Specifically, Drop measures the drop in income experienced by the widow the year after her husband's death relative to the couple's income the year before the husband's death:

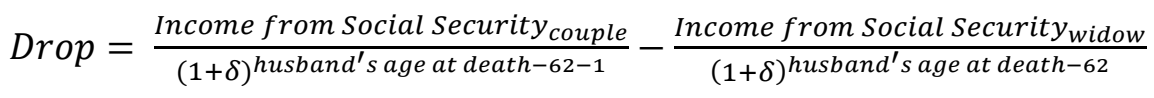

where the husband's expected age at death is estimated from cohort mortality tables, and the couple's and the widow's incomes are both discounted to the year that the husband turns age $62 .^{7}$ For ease of interpretation, the analysis transforms this drop in income to a percentage by dividing by the couple's income before the husband's death. Hence, a value of zero denotes no change in income after the husband's death, while a value of one implies that the widow has no income.

More specifically, Drop measures the percent decrease in combined pension and Social Security income. Pensions and Social Security are considered together because a drop in Social Security benefits may not matter much to a household that receives most of its income from a generous pension with full survivor benefits. However, separating Drop into two variables that separately measure the reduction in Social Security and pension income does not change the conclusion. An alternate definition of Drop might also annuitize financial assets held by the household, such as the balances in defined contribution plans and wealth held in the house. ${ }^{8}$ This analysis adopts the limited definition because most households do not annuitize their financial assets in practice, and tapping home equity - through a home equity loan or reverse mortgage - is equally rare absent an adverse financial shock. ${ }^{9}$ Instead, it controls for these other potential resources in a regression.

\footnotetext{
${ }^{7}$ The husbands in the sample are expected to die between age 80 and 83 , depending on their year of birth. Throughout the analysis, a 5.8 percent discount rate is assumed for consistency with pension wealth variables calculated by Gustman, Steinmeier, and Tabatabai (2010) that are included in the regression and will be discussed in more detail.

${ }^{8}$ Munnell, Hou, and Sanzenbacher (2018).

${ }^{9}$ See Brown (2007 and 2009); Smeeding et al. (2006); and Venti and Wise (2000, 2001, and 2004). Older households are more likely to treat home equity as insurance against adverse financial shocks, such as the death of a spouse or the need for long-term care.
} 
The value of Drop depends on two factors: the existence and generosity of a defined benefit pension, and the level of the wife's labor earnings throughout her career relative to the earnings of her husband. Pension benefits earned the year before the husband's death are reverse-engineered from wealth estimates provided by Gustman, Steinmeier, and Tabatabai (2010) when the husband and wife are each age 62. ${ }^{10}$ The wealth variables are consistent with a scenario in which the pension owner retires no later than age 62 in order to claim Social Security benefits early. ${ }^{11}$ While the claiming decision is technically independent of the decision to retire, the Social Security earnings test discourages workers who claim early from earning substantial labor income. Indeed, Behaghel and Blau (2012) show that the probability of retiring follows a distribution similar to the probability of claiming for workers in the same age cohorts considered in this analysis.

The reverse engineering of pension income employs the same discount rate and mortality tables used in the original wealth calculations (Gustman, Steinmeier, and Tabatabai 2010). ${ }^{12}$ Projecting pension income to the year before the husband's expected death requires adjusting for cost-of-living (COLA) from the year that the benefits are first received, which may occur in the future depending on the plan's retirement provisions. ${ }^{13}$ COLAs granted before the husband turns age 62 mirror those awarded by Social Security. Those granted afterward are based on the assumption that husbands cannot perfectly forecast inflation and instead expect it to stay at the current (age 62) long-run assumption in the Social Security Trustees Report. ${ }^{14}$ After the husband's death, the widow may receive pension survivor benefits. A variable in the HRS asks

\footnotetext{
${ }^{10}$ Gustman, Steinmeier, and Tabatabai (2010) calculate pension wealth for respondents and spouses in the HRS based on the reported characteristics of defined benefit plans, such as the benefit multiplier, final average salary period, and normal retirement age. The pension variables are available in years 1992, 1998, and 2004. Individuals who turn age 62 in 1992 or 1994 receive the 1994 pension values; those who turn age 62 between 1996 and 2000 receive the 1998 pension values; and those who turn age 62 after 2000 receive the 2004 pension values.

${ }^{11}$ In any given year, the pension wealth variables assume that workers retire immediately and have no additional years of earnings credited to the plan (although they may need to wait to claim benefits depending on the plan's normal and early retirement provisions). Workers who retire before 62 receive pension wealth consistent with their actual decisions. The pension wealth variables systematically underestimate wealth for wives who turn 62 after 2004, approximately 1.5 percent of the sample.

12 Munnell et al. (2016) conduct the reverse-engineering.

${ }^{13}$ Unfortunately, the HRS does not collect information on COLA provisions in defined benefit plans. During this period, most private sector defined benefit plans did not adjust benefits for COLA, while public sector defined benefit plans typically provided full adjustments (Foster 1997; and U.S. Bureau of Labor Statistics 2003). The methodology for identifying public sector workers is described in Munnell et al. (2012). Pensions are labeled as public sector if the owner self-reports working for a state or local government between 1992 and 2006.

${ }^{14}$ This assumption is conceptually related to the behavioral economics literature on projection bias. See, for example, Grable et al. (2006); and Loewenstein, O’Donoghue, and Rabin (2003).
} 
whether pension benefits continue unreduced after death, continue reduced, or cease completely. ${ }^{15}$

The second contributor to the value of Drop is the change in the level of Social Security benefits after widowhood, estimated from linked administrative earnings records. ${ }^{16}$ Married individuals are entitled to a Social Security Primary Insurance Amount (PIA) based on their own earnings record, or one-half of their spouse's PIA, whichever is larger. ${ }^{17}$ This benefit receives an actuarial reduction because the individual is assumed to claim early at age 62. ${ }^{18}$ The monthly benefits received by each spouse are adjusted annually for COLA from the year first received until the husband is expected to die. After her husband's death, the widow earns the larger of her own benefit or a survivor benefit based on her husband's earnings record. The survivor benefit is simply a continuation of the Social Security benefit that her husband was receiving while alive, with a further actuarial reduction if the widow claims earlier than her FRA, and with a floor at 82.5 percent of her husband's PIA (adjusted for COLA). ${ }^{19}$

Ultimately, the analysis relates Drop to the husband's claiming age with a linear regression:

$$
\text { Claiming Age } e_{i}=\beta_{0}+\beta_{1} \text { Drop }+\boldsymbol{\gamma} \boldsymbol{X}_{\boldsymbol{i}}+\varepsilon_{i}
$$

\footnotetext{
${ }^{15}$ For simplicity, the analysis calculates a widow's reduced benefit as one-half of the couple's benefit, reduced by 20 years of inflation at 2.5 percent, or 30 percent of the couple's current benefit.

${ }^{16}$ In a few cases, the earnings records cease before age 62 even though the husband reports that he is working. Similarly, some young spouses do not reach age 62 by the 2014 wave of the HRS. In these instances, future earnings are projected assuming no real wage growth and using the long-range intermediate inflation assumption of the 2018 OASDI Trustees Report for years in which actual inflation is unobserved.

${ }^{17}$ For consistency, the Primary Insurance Amount is taken to mean the monthly benefit that a retired worker would receive if he claimed at his Social Security full retirement age. Whenever possible, the analysis calculates PIAs using the program parameters actually in place when the husband or wife turns age 62 . If the wife turns 62 after 2018, the analysis forecasts program parameters using formulas developed by the SSA and the long-range intermediate assumptions of the 2018 OASDI Trustees Report. Because many wives are younger than their husbands, this methodology is slightly inconsistent with the earlier assumption that husbands anticipate future income based solely on economic conditions observed today. It is assumed that husbands get information about their wives' future PIAs from estimates provided by the SSA, such as the Social Security Statement or an online benefits calculator. These PIA estimates incorporate economic forecasts of future inflation and real wage growth, but they do not provide estimates of future COLAs.

18 The actuarial reduction factor is set by the SSA and varies based on the individual's year of birth.

${ }^{19}$ Recall that the husband receives an actuarially reduced PIA because he claims at age 62.
} 
where each household is observed once. ${ }^{20} \boldsymbol{\gamma} \boldsymbol{X}_{\boldsymbol{i}}$ represents a vector of control variables for household characteristics, measured when the husband is age 62. This vector is necessary because the magnitude of Drop is likely correlated with many other household characteristics that could also affect the husband's claiming age. In addition to the standard demographic variables, such as the birth year, race, and education of each spouse, controls are included for the non-pension components of household wealth when the husband is age 62, such as the balance in defined contribution retirement accounts and other financial assets, including housing. ${ }^{21}$ Because defined benefit plans often contain strong incentives to retire at relatively young ages, the vector of controls includes binary indicators for the types of retirement plans owned by the husband and wife: defined benefit, defined contribution, and both (with "none" as the omitted category). The regression also accounts for whether the husband and wife have health conditions that limit work, and the availability of retiree health insurance that would allow either spouse to leave the labor market before becoming eligible for Medicare at age $65{ }^{22}$

\section{Results from the HRS Analysis}

Tables $2 \mathrm{a}$ and $2 \mathrm{~b}$ present summary statistics for the sample of households included in the regression. Nearly all of the husbands are white, 48 percent have more than a high school education, and 55 percent have a defined benefit pension. The average widow experiences a 35 percent drop in projected pension benefits after her husband's death. Similarly, the mean projected drop in Social Security benefits is 36 percent, which is consistent with past research that examines the actual decline in Social Security benefits experienced by new widows (Gillen and Kim, 2009). The mean claiming age of husbands in the sample is 64, but the distribution is bimodal with a large spike at 62 and another smaller spike at 65 - the Social Security full retirement age of most husbands in the sample.

\footnotetext{
${ }^{20}$ The regression is weighted by the value of the HRS household weight variable when the husband is age 62 . Removing the weights does not change the story.

${ }^{21}$ Other financial assets include stocks; bonds; checking, savings, and money market accounts; and other lesscommon assets such as jewelry, trusts, and the present value of an annuity. Only 2 percent of the sample households report receiving annuity income when the husband is age 62 .

22 The health conditions variable is a self-reported assessment of employability. Although several prior studies also consider the self-reported probability of living to 75, the regression coefficients tend to be small in magnitude and not always statistically significant. See Coile et al. (2002); Hurd, Smith, and Zissimopoulos (2004); Goda et al. (2015); and Sass et al. (2007).
} 
Table 3 displays the regression results. The Drop variable in the first column includes both pension and Social Security, while the second column separates the two sources of income. In both specifications, the coefficients on the control variables are generally consistent with past studies and are often statistically significant. ${ }^{23}$ For example, husbands claim earlier when they have a defined benefit pension, retiree health insurance, or a health condition that limits work. The main coefficient of interest, $\beta_{1}$, is marginally statistically significant, but small in magnitude. Husbands whose widows are not projected to face any drop in income claim only half a year earlier than those whose widows face a complete loss of income. Consequently, the mean income drop of 42 percent is associated with only a two-month increase in the claiming age. Separating the income variable into its Social Security and pension components reveals no association between the drop in Social Security income and the husband's claiming age. Instead, husbands seem to respond to the generosity of survivor benefits in their defined benefit pensions, yet even that result is qualitatively small.

One potential concern is that husbands with missing claiming ages could differ systematically from those with valid data, biasing the regression through selective attrition. As a robustness check, Table 4 re-runs the regression reported in column (1) of Table 3 three times, replacing missing claiming ages with age 62 , the average claiming age in the sample, or age 70 depending on the specification. The coefficient on Drop doubles and becomes statistically significant when missing claiming ages are set to age 70 , indicating that selective attrition is a cause for concern in this study and potentially in other HRS analyses that examine the relationship between widows' poverty and husbands' claiming ages.

Another concern is that the Drop calculation ignores differences in expected mortality that could be correlated with the household's earnings history. In particular, men with lower socioeconomic status have been shown to die younger, and will likely discount equation (1) over a shorter time horizon (vice versa for men with high socioeconomic status). ${ }^{24}$ Normalizing the drop in income relative to the prior year's income removes some of this bias, but also masks differences in treatment intensity due to different life expectancies. Consequently, Table 5 performs a robustness check that interacts Drop with a binary indicator equal to one if the

\footnotetext{
${ }^{23}$ See, for example, Coile et al. (2002); Goda et al. (2015); Hurd, Smith, and Zissimopoulos (2004); and Sass et al. (2007).

${ }^{24}$ See, for example, Bosworth, Burtless, and Zhang (2015); and Bosworth and Zhang (2015).
} 
husband has at least a college degree (a proxy variable for socioeconomic status). The coefficient on Drop is small and statistically insignificant regardless of education level.

The strongest story to emerge from the regression analysis is that husbands make their claiming decisions based on immediate concerns such as workplace pension incentives and health conditions. This conclusion is similar to Henriques (2018) and reinforces the view that Social Security survivor benefits are not a salient consideration when husbands and wives make important decisions about when to retire and claim (Sass et al. 2007; Diebold, Moulton, and Scott 2017; and Diebold and Camilleri 2018).

\section{Does Information about Survivor Benefits Alter Husbands' Claiming Decisions?}

This phase of the analysis uses an online experiment to gauge whether a husband's knowledge of how delayed claiming can improve his future widow's well-being affects his claiming behavior. Although Diebold and Camilleri (2018) report promising evidence that information matters - at least in the short-run - exactly what information is needed to change behavior remains unclear. The online experiment developed in this study uses KnowledgePanel®, a nationally representative online research panel administered by GfK that uses probability-based sampling for recruitment. With both random-digit dial (RDD) telephone and address-based sampling (ABS) methodologies, the panel creates a sample frame covering 97\% of the U.S. population. The panel provides participants without a computer with a device and Internet access. GfK maintains a variety of standard demographic and economic variables about panelists, including race, gender, household income, education, and housing status. This study recruits members from the GfK panel who are male, between the ages of 45 and 63, married, and working or looking for work.

To assess the impact of information about survivor benefits on claiming decisions, the study asks participants questions necessary to calculate their Social Security benefits and then randomly assigns them to one of three groups. Members of the first group - the control group see what any visitor to mySocialSecurity will see, which is an estimated Social Security benefit at the FRA, with a link to view a more detailed table of benefit estimates (Exhibit A). ${ }^{25}$ Just like

\footnotetext{
${ }^{25}$ Social Security benefits were estimated by asking survey respondents for their average salary over the past five years. Annual salaries were assumed to grow with the Average Wage Index (AWI) until age 55, at which point they grew with inflation. AWI in years after 2018 was assumed to follow the intermediate long-run assumptions of the 2018 OASDI Trustees Report. Social Security program parameters necessary for calculating future benefits were
} 
on the actual website, clicking on the link leads to a more detailed breakdown of benefits at various claiming ages (Exhibit B). Similar to the control group, participants in in the second group first see their estimated benefit at the FRA, but are then led to a second web page where they view a more detailed explanation of the survivors benefit, are informed about the risk of poverty in widowhood, and are shown estimated benefits for themselves and their survivors at various claiming ages (Exhibits $\mathrm{C} 1$ and $\mathrm{C} 2$ ). Participants in the third group receive the detailed explanation of the survivors benefit, are informed about the risk of poverty in widowhood, and are shown estimated benefits for themselves and a survivor at various claiming ages (Exhibit C2). However, participants in third group do not see the homepage of mySocialSecurity that highlights their own FRA benefit. After viewing this information about benefits, participants in all three groups provide the age at which they intend to claim Social Security. Appendix A includes the full survey instrument.

\section{Methodology}

Since this experiment relies on random assignment to estimate the effect of information on planned claiming age, the empirical approach is straightforward and uses the following regression:

$$
\text { Expected Claiming Age } e_{i}=\alpha+\beta_{1} T_{2, i}+\beta_{2} T_{3, i}+\varepsilon_{i}
$$

where Expected Claiming Age $e_{i}$ denotes the participant's expected claiming age, $\alpha$ is the mean claiming age in the control group, $\beta_{1}$ is the effect of the first intervention (group 2) on claiming age, and $\beta_{2}$ is the effect of the second intervention (group 3). If the additional information increases planned claiming ages, then $\beta_{1}$ and $\beta_{2}$ will be positive and statistically significant. The analysis also examines whether participants with different demographic characteristics respond differently to the interventions by interacting $T_{2, i}$ and $T_{3, i}$ with the widow's potential gain from delayed claiming (D):

$$
\text { Expected Claiming Age } e_{i}=\alpha+\beta_{1} T_{2, i}+\beta_{2} T_{3, i}+\beta_{3} D_{i}+\beta_{4} T_{2, i} D_{i}+\beta_{5} T_{3, i} D_{i}+\varepsilon_{i}
$$

projected based on AWI using formulas provided by the Social Security Administration. All benefit estimates were presented to survey respondents in 2018 real dollars. 
Since the survey does not collect the detailed financial information necessary to precisely calculate a widow's potential gain from delayed claiming by her husband, the regression proxies for $D_{i}$ with the relative magnitudes of the husband's and spouse's earnings. Spouses with earnings greater than or equal to their husbands' are assumed to be less reliant on survivor benefits. The expected result is that the additional information will be most effective among the couples whose surviving spouse would gain most from delayed claiming by the husband; in that case, $\beta_{4}$ and $\beta_{5}$ will be positive and statistically significant. A similar analysis is conducted for the effect of having at least some college education.

\section{Results from the Experiment}

The sample of participants in the experiment includes 1,093 men who responded to the invitation and qualified for the study, with a response rate of 55 percent. Table 6 compares this sample to the corresponding U.S. population using the Current Population Survey. While the experimental sample is broadly similar to the U.S. population, it is younger (by definition) and more diverse than the HRS sample. As expected, given that treatment was randomly assigned, summary statistics also show that key demographic and economic characteristics appear similar across the three groups of participants (Table 7). Moreover, the mean and distribution of participants' stated claiming ages align with recent studies. The mean claiming age of 65.9 is consistent with the average claiming age reported by Diebold and Camilleri (2018), and the distribution shows well-documented spikes at 62, 65, the FRA, and 70 (Figure 1).

Comparing the average claiming age among the three groups reveals an economically meaningless difference, with a claiming age of 65.9 years for the control group compared to 66 and 65.8 for the first and second treated groups, respectively. Linear regression analysis in Table 8 confirms that the economically meaningless difference is also statistically insignificant. Including a vector of control variables does not qualitatively effect the estimated coefficients, nor does it improve statistical precision. Note that the problem is not an insufficient sample size. The experiment has sufficient statistical power to detect a one-year effect on intended claiming age at the 5-percent level, given the standard deviation observed in this sample.

Testing the hypothesis that only men whose wives earn less are affected by the treatment yields a similar result - practically and statistically insignificant differences between the treatment and control groups (column (1) of Table 9). Lastly, men with a college degree or more 
do not respond differently to the information on survivor benefits than those with a high school education or less (column (2) of Table 9).

\section{Interpreting the Experimental Results}

Unlike Diebold and Camilleri (2018), this study does not find that providing information about survivor benefits causes husbands to claim later. To understand the discrepancy, it is important to consider two important differences between the studies: 1) the sample in the current study consists of workers close to retirement -45 to 63 year olds - as opposed to workers ages 30 to 61 in Diebold and Camilleri (2018); and 2) the current study modifies the landing page for Social Security's online portal (mySocialSecurity) instead of an online version of the Social Security Statement. Each of these design differences could have contributed to the divergent findings.

One possibility is that workers closer to retirement may have already made retirement plans and might be less likely to change their plans based on new information. If this is true, younger people in our sample should be more likely to delay claiming if they are in a treatment group. To test this hypothesis, an additional regression in column (3) of Table 9 interacts the treatment variables with a binary variable equal to one if the participant is "young:" ages 45 to 55 (the median age in the sample). The results are inconclusive: younger workers appear to delay claiming more than older workers if they are in a treatment group, but the differences are not statistically significant. Since the current study did not include 30 to 45 year olds, it is not possible to test whether they are more likely to respond to the treatments by delaying their retirement plans.

A more likely possibility is that differences in the presentation of information explain the divergent results. Diebold and Camilleri (2018) modify an online version of the Social Security Statement to show the level of benefits at three claiming ages - 62, the FRA, and 70 - in

ascending order by age. It is important to note that they do not label the ages "early," "full," and “delayed." In contrast, this study modifies Social Security’s online portal, which shows benefits only at the FRA on the main screen, and labels each of the possible claiming ages. The FRA may have served as an anchor (reference point) in the current experiment, overshadowing any effect of the additional information on survivor benefits. If this is the explanation, then one would expect the distribution of claiming ages found in this study to have a more pronounced 
spike at age 67 than that found by Diebold and Camilleri (2018). This hypothesis, unfortunately, is impossible to test without access to their data. However, behavioral anchoring is known to influence Social Security claiming (Brown, Kapteyn, and Mitchell 2013).

\section{Conclusion}

The fact that widows continue to have poverty rates above those of married women has prompted researchers to investigate whether husbands could be persuaded to claim Social Security at older ages in order to enhance their widows' survivor benefits. This study advances the discussion by asking two questions: 1) do husbands in the HRS delay claiming if their wives would otherwise face a large drop in income upon widowhood; and 2) could the SSA encourage husbands with vulnerable spouses to claim later by making simple changes to mySocialSecurity? To answer the second question, the study administered an online survey experiment to 1,093 older husbands. Two interventions provide information about the risk of poverty in widowhood, as well as the level of survivor benefits at different claiming ages, and are specifically designed to be easily implemented by the SSA.

Consistent with the conclusions of past research, this study finds that widows' income is not a driving influence behind husbands' claiming decisions. Instead, husbands respond to immediate concerns such as workplace pension incentives and health conditions. It also finds that increasing the salience of the probability and economic consequences of widowhood does not alter the stated claiming ages of older husbands. This second finding is seemingly at odds with a recent study by Diebold and Camilleri (2018), who find an increase in stated claiming ages among participants who receive information about the Social Security survivor benefits, although the effect of the information in that study faded within three months. While it is difficult to disentangle discrepancies in experimental results without additional experiments, a likely explanation is that seemingly insignificant design choices, like presenting the Social Security FRA as the default, affects short-term claiming intentions. For example, Diebold and Camilleri (2018) find that detailed new information about how survivor benefits are calculated has a weaker effect than increasing the salience of survivor benefits in the existing Social Security Statement. In an online experiment with limited real-world consequences, the welldocumented tendency of people to focus on a limited amount of information and rely on 
cognitive shortcuts could overshadow the effect of information designed to have a lasting educational impact.

Considered together, the HRS and experimental results suggest that simply offering information online is unlikely to improve widows' economic outcomes. Examining the husband's decision from a behavioral perspective provides intuition for this conclusion. To pick a claiming age based on survivor benefits, the husband first has to think about an uncertain event that he would rather avoid and that will occur in the distant future. Then he must make complicated financial projections about the amount of additional resources that his surviving spouse will need in the undesired situation. These are significant behavioral barriers, many of which impede seemingly rational behavior in many other aspects of retirement planning and insurance, such as enrolling in a 401(k) plan at a young age or deciding to purchase long-term disability insurance.

Since the behavioral hurdles to considering widows' economic security are unlikely to change, an alternate approach might consider how to protect widows without relying on husbands to delay claiming their Social Security benefits. Decoupling the survivor benefit from the husband's claiming decision is not a new idea. ${ }^{26}$ For example, many proposals to restructure Social Security would increase the survivor benefit to 75 percent of the couple's total Social Security benefit, sometimes with a dollar cap to target the enhancement toward low-income widows. ${ }^{27}$ The enhanced survivor benefit could be funded by reducing the benefit that dependent spouses receive while their husbands are still alive. Although the survivor benefits in this proposal are still partially determined by the husband's benefit - they are actuarially reduced if he claims early - the link is mediated by the wife's benefit, which she could increase by claiming later.

\footnotetext{
${ }^{26}$ For example, Sass, Sun, and Webb (2007) also make this point.

${ }^{27}$ See, for example, Anzick and Weaver (2001); Diamond and Orszag (2004); Entmacher (2009); Hurd and Wise (1991); President's Commission to Strengthen Social Security (2001); and Smeeding, Estes, and Glasse (1999).
} 


\section{References}

Angel, Jacqueline L., Maren A. Jimenez, and Ronald J. Angel. 2007. “The Economic Consequences of Widowhood for Older Minority Women." The Gerontologist 47(2): 224-234.

Anzick, Michael and David A. Weaver. 2001. Reducing Poverty among Elderly Women. Working Paper No. 87. Washington, DC: U.S. Social Security Administration, Office of Research, Evaluation and Statistics.

Behaghel, Luc and David M. Blau. 2012. "Framing Social Security Reform: Behavioral Responses to Changes in the Full Retirement Age." American Economic Journal: Economic Policy 4(4): 41-67.

Biggs, Andrew G. 2010. "Improving the Social Security Statement.” Working Paper WR-794SSA. Santa Monica, CA, and Hanover, NH: Financial Literacy Center.

Bosworth, Barry P., Gary Burtless, and Kan Zhang. 2015. "Sources of Increasing Differential Mortality among the Aged by Socioeconomic Status." Working Paper 2015-10. Chestnut Hill, MA: The Center for Retirement Research at Boston College.

Bosworth, Barry P. and Kan Zhang. 2015. "Evidence of Increasing Differential Mortality: A Comparison of the HRS and SIPP." Working Paper 2015-13. Chestnut Hill, MA: The Center for Retirement Research at Boston College.

Brown, Jeffrey R. 2007. "Rational and Behavior Perspectives on the Role of Annuities in Retirement Planning. Working Paper 13537. Cambridge, MA: National Bureau of Economic Research.

Brown, Jeffrey R. 2009. "Financial Education and Annuities." OECD Journal General Papers 2008(3):173-215.

Brown, S. Kathi and Rebecca Perron. 2011. "Determining How Current and Future Social Security Beneficiaries Make Retirement Decisions." Washington, DC: AARP Research and Strategic Analysis.

Coile, Courtney, Peter Diamond, Jonathan Gruber, and Alain Jousten. 2002. "Delays in claiming Social Security benefits.” Journal of Public Economics 84(?): 357-385.

Diebold, Jeffrey, Jeremy Moulton, and John Scott. 2017. "Early claiming of higher-earning husbands, the survivor benefit, and the incidence of poverty among recent widows." Journal of Pension Economics and Finance 16(4): 485-508.

Diebold, Jeffrey and Susan Camilleri. 2018. "An experimental analysis of modifications to the survivor benefit information within the Social Security statement." Journal of Pension Economics and Finance (forthcoming). 
Diamond, Peter. A and Peter R. Orszag. 2004. Saving Social Security. Washington, DC: Brookings Institution Press.

Entmacher, Joan. 2009. "Strengthening Social Security Benefits for Widow(er)s: The 75-Percent Solution." In Strengthening Social Security for Vulnerable Groups, edited by Virginia P. Reno and Joni Lavery, 23-26. Washington, DC: National Academy of Social Insurance.

Foster, Ann C. 1997. "Public and Private Sector Defined Benefit Pensions: A Comparison." Compensation and Working Conditions Summer: 37-43.

Gillen, Martie and Hyungsoo Kim. 2009. "Older Women and Poverty Transition: Consequences of Income Source Changes from Widowhood." Journal of Applied Gerontology 28(30): 320-341.

Goda, Gopi Shah, Shanthi Ramnath, John B. Shoven, and Sita Nataraj Slavov. 2015. "The Financial Feasibility of Delaying Social Security: Evidence from Administrative Tax Data.” Working Paper No. 21544. Cambridge, MA: The National Bureau of Economic Research.

Grable, John, Ruth H. Lytton, Barbara O'Neill, So-Hyun Joo, and Derek Klock. 2006. "Risk Tolerance, Projection Bias, Vividness, and Equity Prices.” The Journal of Investing 15(2): 68-74.

Henriques, Alice M. 2018. "How Does Social Security Claiming Respond to Incentives? Considering Husbands' and Wives' Benefits Separately." The Journal of Human Resources 53(2): 382-413.

Hungerford, Thomas L. 2001. "The Economic Consequences of Widowhood on Elderly Women in the United States and Germany." The Gerontologist 41(1): 103-110.

Hurd, Michael D., James P. Smith, and Julie M. Zissimopoulos. 2004. "The Effects of Subjective Survival on Retirement and Social Security Claiming." Journal of Applied Econometrics 19(6): 761-775.

Hurd, Michael D. and David A. Wise. 1991. "Changing Social Security Survivorship Benefits and the Poverty of Widows." Working Paper No. 3833. Cambridge, MA: National Bureau of Economic Research.

Liebman, Jeffrey B., and Erzo F. P. Luttmer. 2012. "The Perception of Social Security Incentives for Labor Supply and Retirement: The Median Voter Knows More Than You'd Think." In Tax Policy and the Economy, Vol. 26, edited by Jeffrey R. Brown, 1-42. Chicago: University of Chicago Press.

Loewenstein, George, Ted O'Donoghue, and Matthew Rabin. 2003. "Projection Bias in Predicting Future Utility.” The Quarterly Journal of Economics 118(4): 1209-1248. 
Mastrobuoni, Giovanni. 2011. "The Role of Information for Retirement Behavior: Evidence Based on the Stepwise Introduction of the Social Security Statement." Journal of Public Economics 95(7-8): 913-925.

McGarry, Kathleen and Robert F. Schoeni. 2005. "Widow(er) Poverty and Out-Of-Pocket Medical Expenditures Near the End of Life. Journal of Gerontology: Social Sciences 60B(3): S160-S168.

Munnell, Alicia H., Jean-Pierre Aubry, Joshua Hurwitz, and Laura Quinby. 2012. "Public Plans and Short-Term Employees." Working Paper No. 18448. Cambridge, MA: The National Bureau of Economic Research.

Munnell, Alicia H., Wenliang Hou, Anthony Webb, and Yinji Li. 2016. "Pension Participation, Wealth, and Income: 1992-2010." Working Paper 2016-3. Chestnut Hill, MA: The Center for Retirement Research at Boston College.

Munnell, Alicia H., Wenliang Hou, and Geoffrey T. Sanzenbacher. 2018. "National Retirement Risk Index Shows Modest Improvement in 2016." Issue in Brief 18-1. Chestnut Hill, MA: The Center for Retirement Research at Boston College.

Mutchler, Jan, Yang Li, and Ping Xu. 2017. "Living Below the Line: Economic Insecurity and Older Americans, Gender Disparities in Insecurity, 2016." Center for Social and Demographic Research on Aging Publications 19. Boston, MA: The Gerontology Institute at the University of Massachusetts Boston.

President's Commission to Strengthen Social Security. 2001. Strengthening Social Security and Creating Personal Wealth for All Americans. Washington, DC.

Sass, Steven A., Wei Sun, and Anthony Webb. 2007. "Why Do Married Men Claim Social Security Benefits So Early? Ignorance or Caddishness?” Working Paper 2007-17. Chestnut Hill, MA: The Center for Retirement Research at Boston College.

Sevak, Purvi, David R. Weir, and Robert J. Willis. 2003. "The Economic Consequences of a Husband's Death: Evidence from the HRS and AHEAD." The Social Security Bulletin 65(3): 31-44.

Smeeding, Timothy M., Carroll L. Estes, and Lou Glasse. 1999. "Social Security and Older Women: Improving the System." Income Security Policy Series Paper No. 22. Syracuse, NY: Syracuse University, Maxwell School of Citizenship and Public Affairs.

Smeeding, Timothy M. and Susanna Sandstrom. 2004. "Poverty and Income Maintenance in Old Age: A Cross-National View of Low-Income Older Women.” Working Paper 2004-29. Chestnut Hill, MA: The Center for Retirement Research at Boston College. 
Smeeding, Timothy M., Barbara Boyle Torrey, Jonathan Fisher, David S. Johnson, and Joseph Marchand. 2006. "No Place Like Home: Older Adults and their Housing." Working Paper 2006-16. Chestnut Hill, MA: Center for Retirement Research at Boston College.

Smith, Barbara A. and Kenneth A. Couch. 2014. "How Effective Is the Social Security Statement? Informing Younger Workers about Social Security." Social Security Bulletin 74(4): 1-19.

U.S. Bureau of Labor Statistics. 2003. National Compensation Survey: Employee Benefits in Private Industry in the United States, 2000, Table 60. Washington, DC.

Venti, Steven F. and David A. Wise. 2000. "Aging and Housing Equity.” Working Paper 7882. Cambridge, MA: National Bureau of Economic Research.

Venti, Steven F. and David A. Wise. 2001. "Aging and Housing Equity: Another Look." Working Paper 8608. Cambridge, MA: National Bureau of Economic Research.

Venti, Steven F. and David A. Wise. 2004. “Aging and Housing Equity: Another Look." In Perspectives on the Economics of Aging, edited by David A. Wise, 127-180. Chicago, Illinois: University of Chicago Press.

Weaver, David A. 2010. "Widows and Social Security." Social Security Bulletin 70(3): 89-109.

Zick, Cathleen D. and Karen Holden. 2000. "An Assessment of the Wealth Holdings of Recent Widows." Journal of Gerontology: Social Sciences 55B(2): S90-S97.

Zick, Cathleen D., Jessie X. Fan, and Kuo-Liang Chang. 2004. "Impending widowhood and health care spending." Social Science Research 33(3): 538-555. 
Table 1. Sample Selection for the HRS Analysis

\begin{tabular}{lr}
\hline Sample restriction & Count \\
\hline Full HRS Sample & 37,495 \\
Men & 16,424 \\
Born between 1931-1943 & 5,507 \\
Married at age 62 & 3,452 \\
Never claimed disability benefits & 3,020 \\
Spouse turns 62 before husband dies & 2,970 \\
Valid claiming age & 2,640 \\
Claiming age is after age 61 & 2,545 \\
Shared their earnings history with HRS & 2,264 \\
Spouse shared their earnings history & 1,894 \\
Qualify for Social Security benefits & 1,870 \\
Spouse is alive when husband is assumed to die & 1,867 \\
No other missing variables & 1,847 \\
\hline
\end{tabular}

Source: Authors' calculations from the Health and Retirement Study (HRS), 1992-2014. 
Table 2a. Characteristics of Households in the HRS Sample When the Husband is Age 62 (continued in Table 2b)

\begin{tabular}{lc}
\hline Characteristic & Percent of husbands \\
\hline Race & $93 \%$ \\
$\quad$ White & 4 \\
$\quad$ Black & 3 \\
$\quad$ Other & 17 \\
Education & 35 \\
$\quad$ Less than high school & 20 \\
$\quad$ High school & 28 \\
$\quad$ Some college & 13 \\
College & 19 \\
Health limits ability to work & 43 \\
Health limits spouse's ability to work & 20 \\
Has retiree health insurance & \\
Spouse has retiree health insurance & 39 \\
Pension coverage & 15 \\
DB pension only & 15 \\
DC pension only & \\
DB and DC pension & 21 \\
Region & 26 \\
$\quad$ Northeast & 34 \\
Midwest & 20 \\
South & \\
$\quad$ West
\end{tabular}

Source: Authors' calculations from the HRS, 1992-2014. 
Table 2b. Characteristics of Households in the HRS Sample When the Husband is Age 62 (continued from Table 2a)

\begin{tabular}{lrrrr}
\hline & Mean & SD & Min & Max \\
\hline Average claim age & 64 & 2 & 62 & 73 \\
Spouse's age when husband age 62 & 59 & 5 & 44 & 81 \\
Number of household residents & 3 & 1 & 2 & 14 \\
Household wealth & $\$ 267,300$ & $\$ 668,888$ & $\$ 0$ & $\$ 9,218,316$ \\
& $-35 \%$ & $42 \%$ & $-\% \%$ & $0 \%$ \\
Share change in pension income & $-36 \%$ & $8 \%$ & $-52 \%$ & $6 \%$ \\
Share change in SSA income & & & &
\end{tabular}

Source: Authors' calculations from the HRS, 1992-2014. 
Table 3. Regression Results of the Husband's Claiming Age on Household Characteristics

\begin{tabular}{|c|c|c|}
\hline Variable & $\begin{array}{l}\text { Husband's } \\
\text { claiming age }\end{array}$ & $\begin{array}{l}\text { Husband's } \\
\text { claiming age }\end{array}$ \\
\hline \multirow{2}{*}{ Drop in SSA income } & -- & 0.154 \\
\hline & -- & 0.575 \\
\hline \multirow[t]{2}{*}{ Drop in DB income } & -- & $-0.285^{* * *}$ \\
\hline & -- & 0.097 \\
\hline \multirow[t]{2}{*}{ Drop in income } & $-0.470 *$ & \\
\hline & 0.286 & \\
\hline \multirow[t]{2}{*}{ Only DC coverage } & 0.764 & 0.739 \\
\hline & 0.127 & 0.128 \\
\hline \multirow[t]{2}{*}{ Only DB coverage } & $-0.206^{* *}$ & $-0.283 * * *$ \\
\hline & 0.098 & 0.102 \\
\hline \multirow[t]{2}{*}{ DC and DB coverage } & $0.394 * * *$ & $0.309 * * *$ \\
\hline & 0.137 & 0.141 \\
\hline \multirow[t]{2}{*}{ Spouse only has DC coverage } & $0.412 * * *$ & $0.420 * * *$ \\
\hline & 0.133 & 0.133 \\
\hline \multirow[t]{2}{*}{ Spouse only has DB coverage } & 0.076 & 0.079 \\
\hline & 0.108 & 0.108 \\
\hline \multirow[t]{2}{*}{ Spouse has DC and DB coverage } & 0.111 & 0.096 \\
\hline & 0.150 & 0.151 \\
\hline \multirow[t]{2}{*}{ Wealth tercile 1} & 0.096 & 0.103 \\
\hline & 0.114 & 0.114 \\
\hline \multirow[t]{2}{*}{ Wealth tercile 2} & -0.050 & -0.057 \\
\hline & 0.101 & 0.101 \\
\hline \multirow[t]{2}{*}{ Housing wealth tercile 1} & -0.017 & -0.011 \\
\hline & 0.108 & 0.108 \\
\hline \multirow[t]{2}{*}{ Housing wealth tercile 2} & 0.132 & 0.133 \\
\hline & 0.102 & 0.101 \\
\hline \multirow[t]{2}{*}{ Has retiree health insurance } & $-0.257 * * *$ & $-0.269 * * *$ \\
\hline & 0.085 & 0.085 \\
\hline \multirow[t]{2}{*}{ Spouse has retiree health insurance } & $-0.363 * * *$ & $-0.360 * * *$ \\
\hline & 0.109 & 0.109 \\
\hline \multirow[t]{2}{*}{ Health limits ability to work } & $-0.315 * * *$ & $-0.303 * * *$ \\
\hline & 0.114 & 0.114 \\
\hline \multirow[t]{2}{*}{ Health limits spouse's ability to work } & 0.012 & 0.007 \\
\hline & 0.097 & 0.096 \\
\hline
\end{tabular}

-continued- 
Table 3. Regression Results of the Husband's Claiming Age on Household Characteristics (cont'd)

\begin{tabular}{lcc}
\hline Variable & $\begin{array}{c}\text { Husband's } \\
\text { claiming age }\end{array}$ & $\begin{array}{c}\text { Husband's } \\
\text { claiming age }\end{array}$ \\
\hline White & 0.088 & 0.101 \\
& 0.213 & 0.213 \\
Black & -0.002 & 0.004 \\
College degree & 0.253 & 0.254 \\
& $0.391^{* *}$ & 0.405 \\
Spouse has a college degree & 0.107 & 0.108 \\
& 0.297 & $0.294^{* *}$ \\
Number of people in household & 0.119 & 0.119 \\
& $0.134^{* * *}$ & $0.131^{* * *}$ \\
Constant & 0.043 & 0.043 \\
& 62.835 & $62.513^{* * *}$ \\
Birth year fixed effects & 2.943 & 2.961 \\
Spouse's age & Yes & Yes \\
Spouse's age squared & Yes & Yes \\
Region fixed effects & Yes & Yes \\
R-squared & Yes & Yes \\
Number of observations & 0.122 & 0.125 \\
\hline
\end{tabular}

Notes: Robust standard errors in parentheses. ${ }^{* * *} \mathrm{p}<0.01,{ }^{* *} \mathrm{p}<0.05,{ }^{*} \mathrm{p}<0.1$

Source: Authors' estimates from the HRS, 1992-2014. 
Table 4. Regression Results Replacing Missing Claiming Ages with Hypothetical Values

\begin{tabular}{|c|c|c|c|}
\hline Variable & $\begin{array}{l}\text { Replace with } \\
\text { age } 62\end{array}$ & $\begin{array}{c}\text { Replace with } \\
\text { age } 64\end{array}$ & $\begin{array}{c}\text { Replace with } \\
\text { age } 70\end{array}$ \\
\hline \multirow[t]{2}{*}{ Drop in income } & -0.277 & $-0.459 *$ & $-1.006^{* *}$ \\
\hline & 0.271 & 0.261 & 0.413 \\
\hline \multirow[t]{2}{*}{ Only DC coverage } & 0.650 & 0.706 & 0.876 \\
\hline & 0.124 & 0.117 & 0.176 \\
\hline \multirow[t]{2}{*}{ Only DB coverage } & $-0.164 *$ & $-0.216 * *$ & $-0.373 * * *$ \\
\hline & 0.094 & 0.093 & 0.137 \\
\hline \multirow[t]{2}{*}{ DC and DB coverage } & $0.369 * * *$ & $0.358 * * *$ & $0.326 *$ \\
\hline & 0.132 & 0.130 & 0.182 \\
\hline \multirow[t]{2}{*}{ Spouse only has DC coverage } & $0.372 * * *$ & $0.383 * * *$ & $0.417 * *$ \\
\hline & 0.130 & 0.124 & 0.172 \\
\hline \multirow[t]{2}{*}{ Spouse only has DB coverage } & 0.030 & 0.078 & 0.223 \\
\hline & 0.105 & 0.101 & 0.145 \\
\hline \multirow[t]{2}{*}{ Spouse has DC and DB coverage } & 0.112 & 0.120 & 0.146 \\
\hline & 0.145 & 0.144 & 0.208 \\
\hline \multirow[t]{2}{*}{ Wealth tercile 1} & 0.059 & 0.092 & 0.189 \\
\hline & 0.111 & 0.108 & 0.152 \\
\hline \multirow[t]{2}{*}{ Wealth tercile 2} & -0.068 & -0.036 & 0.061 \\
\hline & 0.097 & 0.094 & 0.136 \\
\hline \multirow[t]{2}{*}{ Housing wealth tercile 1} & -0.022 & -0.015 & 0.004 \\
\hline & 0.104 & 0.101 & 0.147 \\
\hline \multirow[t]{2}{*}{ Housing wealth tercile 2} & 0.138 & 0.113 & 0.039 \\
\hline & 0.099 & 0.096 & 0.133 \\
\hline \multirow[t]{2}{*}{ Has retiree health insurance } & $-0.259 * * *$ & $-0.233 * * *$ & -0.153 \\
\hline & 0.083 & 0.082 & 0.118 \\
\hline \multirow[t]{2}{*}{ Spouse has retiree health insurance } & $-0.334 * * *$ & $-0.326 * * *$ & $-0.303 * *$ \\
\hline & 0.105 & 0.103 & 0.147 \\
\hline \multirow[t]{2}{*}{ Health limits ability to work } & $-0.341 * * *$ & $-0.277 * * *$ & -0.084 \\
\hline & 0.106 & 0.105 & 0.167 \\
\hline \multirow[t]{2}{*}{ Health limits spouse's ability to work } & -0.003 & 0.031 & 0.133 \\
\hline & 0.093 & 0.090 & 0.144 \\
\hline \multirow[t]{2}{*}{ White } & 0.121 & 0.098 & 0.031 \\
\hline & 0.212 & 0.199 & 0.311 \\
\hline \multirow[t]{2}{*}{ Black } & -0.008 & 0.048 & 0.218 \\
\hline & 0.244 & 0.234 & 0.372 \\
\hline \multirow[t]{2}{*}{ College degree } & $0.349 * * *$ & 0.365 & $0.414 * * *$ \\
\hline & 0.105 & 0.102 & 0.135 \\
\hline
\end{tabular}

-continued- 
Table 4. Regression Results Replacing Missing Claiming Ages with Hypothetical Values (cont'd)

\begin{tabular}{lccc}
\hline Variable & $\begin{array}{c}\text { Replace with } \\
\text { age } 62\end{array}$ & $\begin{array}{c}\text { Replace with } \\
\text { age } 64\end{array}$ & $\begin{array}{c}\text { Replace with } \\
\text { age } 70\end{array}$ \\
\hline Spouse has a college degree & $0.316^{* * *}$ & $0.269^{* *}$ & 0.130 \\
Number of people in household & 0.117 & 0.113 & 0.150 \\
Constant & $0.122^{* * *}$ & $0.126^{* * *}$ & $0.139^{* *}$ \\
& 0.042 & 0.041 & 0.056 \\
Birth year fixed effects & 63.212 & 63.227 & 63.273 \\
Spouse's age & 2.873 & 2.868 & 3.994 \\
Spouse's age squared & Yes & Yes & Yes \\
Region fixed effects & Yes & Yes & Yes \\
R-squared & Yes & Yes & Yes \\
Number of observations & Yes & Yes & Yes \\
\hline
\end{tabular}

Notes: Robust standard errors in parentheses. $* * * \mathrm{p}<0.01, * * \mathrm{p}<0.05, * \mathrm{p}<0.1$

Source: Authors' estimates from the HRS, 1992-2014. 
Table 5. Regression Results Testing for a Differential Association between Widows' Vulnerability and Claiming by Education

\begin{tabular}{lc}
\hline Variable & Husband's claiming age \\
\hline Drop in income & -0.457 \\
& 0.336 \\
Interaction of college and drop in income & -0.035 \\
& 0.597 \\
Only DC coverage & $0.764^{* * *}$ \\
& 0.127 \\
Only DB coverage & $-0.206^{* *}$ \\
& 0.098 \\
DC and DB coverage & $0.395^{* * *}$ \\
Spouse only has DC coverage & 0.138 \\
& $0.412^{* * *}$ \\
Spouse only has DB coverage & 0.133 \\
& 0.076 \\
Spouse has DC and DB coverage & 0.107 \\
& 0.111 \\
Wealth tercile 1 & 0.150 \\
Wealth tercile 2 & 0.096 \\
& 0.114 \\
Housing wealth tercile 1 & -0.050 \\
& 0.101 \\
Housing wealth tercile 2 & -0.073 \\
& 0.108 \\
Has retiree health insurance & 0.132 \\
Spouse has retiree health insurance & 0.102 \\
Health limits ability to work & $-0.257^{* * *}$ \\
Health limits spouse's ability to work & 0.085 \\
White & $-0.363^{* * *}$ \\
Black & 0.109 \\
College degree & $-0.316^{* * *}$ \\
& 0.114 \\
& 0.114 \\
& 0.096 \\
& 0.088 \\
& 0.214 \\
& -0.001 \\
& 0.253 \\
& 0.376 \\
& 0.262 \\
\hline & \\
& \\
&
\end{tabular}

-continued- 
Table 5. Regression Results Testing for a Differential Association between Widows' Vulnerability and Claiming by Education (cont'd)

\begin{tabular}{lc}
\hline Variable & Husband's claiming age \\
\hline Spouse has a college degree & $0.297^{*}$ \\
& 0.119 \\
Number of people in household & $0.134^{* * *}$ \\
& 0.043 \\
Constant & 62.848 \\
& 2.952 \\
\hline Birth year fixed effects & Yes \\
Spouse's age & Yes \\
Spouse's age squared & Yes \\
Region fixed effects & Yes \\
R-squared & 0.122 \\
Number of observations & 1,847 \\
\hline
\end{tabular}

Notes: Robust standard errors in parentheses. ${ }^{* * *} \mathrm{p}<0.01,{ }^{*} \mathrm{p}<0.05$.

Source: Authors' estimates from the HRS, 1992-2014. 
Table 6. Mean Characteristics of Survey Participants Compared to the Corresponding U.S. Population

\begin{tabular}{lcc}
\hline Characteristic & Survey sample & U.S. population \\
\hline Age & 54 & 54 \\
Salary in 2016 & -- & $\$ 76,229$ \\
Average salary past five years & $\$ 71,135$ & -- \\
Employed & $98 \%$ & $97 \%$ \\
White, non-Hispanic & 70 & 70 \\
Black, non-Hispanic & 8 & 8 \\
Hispanic & 14 & 14 \\
College or professional degree & 40 & 39 \\
\hline
\end{tabular}

Note: The summary statistics include married men ages 45-63 who are either working or looking for work. Source: Authors' calculations from an online survey experiment and the Current Population Survey (2017).

Table 7. Mean Characteristics of Survey Participants by Treated Status

\begin{tabular}{lccc}
\hline Variable & Control group & $\begin{array}{c}\text { Group 2 } \\
\text { (first treated group) }\end{array}$ & $\begin{array}{c}\text { Group 3 } \\
\text { (second treated group) }\end{array}$ \\
\hline Age & 55 & 56 & 54 \\
& $(5.1)$ & $(5.0)$ & $(5.2)$ \\
Average husbands income & $\$ 74,093$ & $\$ 75,175$ & $\$ 74,566$ \\
& $(35,465)$ & $(34,766)$ & $(33,376)$ \\
Average wife's income & 47,781 & 43,965 & 43,753 \\
& $(55,052)$ & $(39,541)$ & $(39048)$ \\
Percent white, non-Hispanic & $78 \%$ & $79 \%$ & $78 \%$ \\
Percent with college degree & 52 & 49 & 51 \\
\hline Number of observations & 364 & 360 & 352 \\
\hline
\end{tabular}

Note: Standard deviations are in parentheses.

Source: Authors' calculations from an online survey experiment. 
Table 8. Effect of Two Information Treatments on Husbands' Intended Claiming Age

\begin{tabular}{lcc}
\hline & \multicolumn{2}{c}{ Claiming age } \\
\cline { 2 - 3 } Variables & $(1)$ & $(2)$ \\
\hline First treated group (binary) & 0.0716 & 0.185 \\
& $(0.208)$ & $(0.198)$ \\
Second treated group (binary) & -0.0615 & -0.0280 \\
& $(0.203)$ & $(0.197)$ \\
Constant & $65.95^{* * *}$ & $62.30^{* * *}$ \\
& $(0.147)$ & $(1.481)$ \\
\hline Observations & & \\
\hline R-squared & 1,076 & 1,075 \\
Age dummies & 0.001 & 0.105 \\
Employment status dummies & & Yes \\
Education dummies & & Yes \\
Race dummies & & Yes \\
Household size & & Yes \\
Log household income & & Yes \\
Spouse earns less dummy & & Yes \\
Financial importance of Social Security dummies & & Yes \\
\hline
\end{tabular}

Note: Robust standard errors are in parentheses. ${ }^{* * *}<<0.01$.

Source: Authors' estimates from an online survey experiment. 
Table 9. Difference in the Effect of Two Information Treatments on Husbands' Intended Claiming Age, by Spousal Earnings and Husbands' Education

\begin{tabular}{|c|c|c|c|}
\hline \multirow[b]{2}{*}{ Variables } & \multicolumn{3}{|c|}{ Claiming age } \\
\hline & $(1)$ & $(2)$ & (3) \\
\hline \multirow[t]{2}{*}{ First treated group } & 0.135 & 0.0485 & -0.0793 \\
\hline & $(0.258)$ & $(0.339)$ & $(0.332)$ \\
\hline \multirow[t]{2}{*}{ Second treated group } & -0.315 & 0.0263 & -0.398 \\
\hline & $(0.280)$ & $(0.353)$ & $(0.331)$ \\
\hline \multirow[t]{2}{*}{ Spouse earns more $*$ first treated group } & -0.151 & & \\
\hline & $(0.593)$ & & \\
\hline \multirow[t]{2}{*}{ Spouse earns more $*$ second treated group } & 0.760 & & \\
\hline & $(0.583)$ & & \\
\hline \multirow[t]{2}{*}{ At least a college degree $*$ first treated group } & & 0.146 & \\
\hline & & $(0.468)$ & \\
\hline \multirow[t]{2}{*}{ At least a college degree $*$ second treated group } & & -0.462 & \\
\hline & & $(0.458)$ & \\
\hline \multirow[t]{2}{*}{ Young * first treated group } & & & 0.303 \\
\hline & & & $(0.470)$ \\
\hline \multirow[t]{2}{*}{ Young $*$ second treated group } & & & 0.387 \\
\hline & & & $(0.471)$ \\
\hline \multirow[t]{2}{*}{ Constant } & $64.11 * * *$ & $64.11 * * *$ & $65.41 * * *$ \\
\hline & $(1.459)$ & $(1.466)$ & $(1.433)$ \\
\hline Observations & 1,076 & 1,076 & 1,076 \\
\hline R-squared & 0.104 & 0.103 & 0.101 \\
\hline Age dummies & Yes & Yes & Yes \\
\hline Employment status dummies & Yes & Yes & Yes \\
\hline Education dummies & Yes & Yes & Yes \\
\hline Race dummies & Yes & Yes & Yes \\
\hline Household size & Yes & Yes & Yes \\
\hline Log household income & Yes & Yes & Yes \\
\hline Spouse earns more dummy & Yes & Yes & Yes \\
\hline
\end{tabular}

Note: Robust standard errors are in parentheses. ${ }^{* * *} \mathrm{p}<0.01$.

Source: Authors' estimates from an online survey experiment. 
Figure 1. Distribution of Intended Claiming Ages among Survey Participants

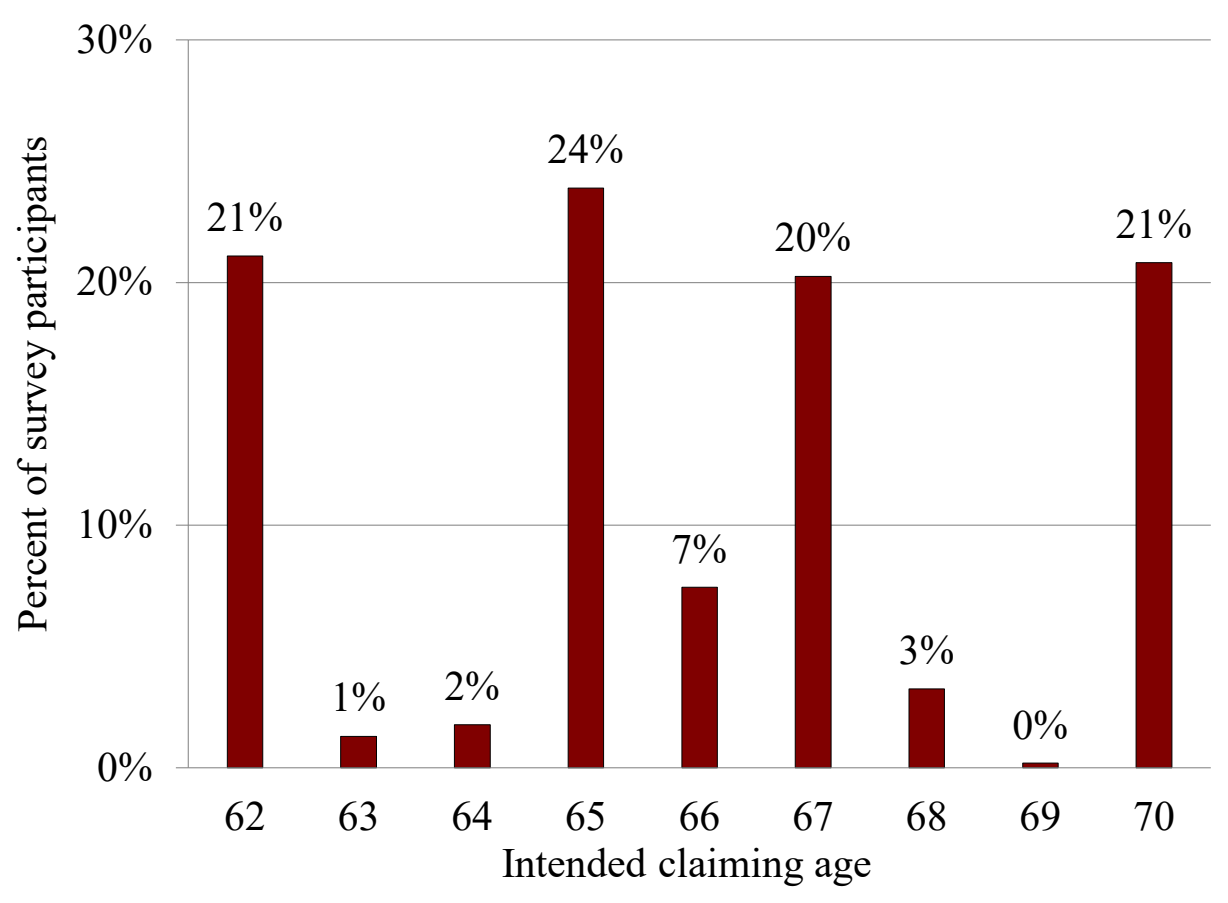

Source: Authors' calculations from an online survey experiment. 
Exhibit A. Online Information Presented to the Experimental Control Group

Estimated Benefit at Full

$\$ 2,723$ a month

$\ulcorner$ View Estimated Benefits

Retirement age (67):

Exhibit B. Screenshot of the "View Estimated Benefits" Link in Exhibit A

\section{Your Estimated Benefits}

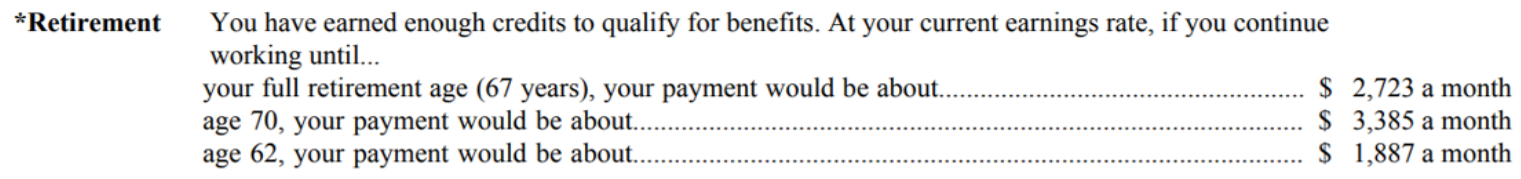

Please note that the benefits shown above are a rough estimate based on limited information about your workhistory. For a more precise estimate based on your full work history, please visit www.ssa.gov/myaccount/ 


\section{Exhibit C1. Online Information Presented to the First Treated Group (First Web Page) \\ Estimated Benefit at Full \\ $\$ 2,723$ a month \\ View Estimated Benefits \\ Retirement age (67):}

\section{Exhibit C2. Online Information Presented to the First Treated Group (Subsequent Web Page)}

Once you claim your Social Security benefit, you will receive monthly income from Social Security as long as you live. Your surviving spouse will also be entitled to a monthly benefit for life if he/she outlives you.

The benefits that your surviving spouse might receive as a widow are important to consider because, on average, women outlive men by 2.5 years, and 1 in 6 widows live in poverty.

The benefits you and your spouse are entitled to will depend on your claiming age:

Estimated Social Security Benefits

\begin{tabular}{|l|l|l|}
\hline Your claiming age & $\begin{array}{l}\text { Your monthly retirement benefit } \\
\text { amount }\end{array}$ & $\begin{array}{c}\text { Your surviving spouse 's monthly } \\
\text { benefit as a widow/widower* }\end{array}$ \\
\hline 62 - first eligible & & \\
\hline $66 / 67-$ full retirement age & & \\
\hline $70-$ latest claiming age & & \\
\hline
\end{tabular}

* If your surviving spouse has earned more than you over her lifetime, she will keep her own (higher) benefit as a widow.

Waiting to claim until your full retirement age of $<66 / 67>$ could help your spouse avoid poverty if he/she becomes widowed.

Please note that the benefits shown above are a rough estimate based on limited information about your work-history. For a more precise estimate based on your full work history, please visit www.ssa.gov/myaccount/ 


\section{Appendix A: Survey Questionnaire}

\section{Base: all respondents}

Prompt once if refused, if still refused, please terminate

QMARIT [S]

Are you now...?

Select one answer only.

1. Married

2. Widowed

3. Divorced

4. Separated

5. Never married

Please terminate if QMARIT NE 1

\section{Base: all respondents}

AGECONS [Q]

How old are you?

[PROMPT]

Your answer will help represent the entire U.S. population and will be kept confidential. Thank you!

Type in your age.

SCRIPTER: min. $=0$, max. $=120$. Show label to right of box: years old Prompt following nonresponse.

Please terminate if AGECONS is not between 45 and 63 


\section{EMPLOYMENT [S]}

Which statement best describes your current employment status?

Working - as a paid employee ........1

Working self-employed ..................2

Not working - on temporary layoff from a job ............................... 3

Not working - looking for work .....4

Not working - retired .....................5

Not working - disabled ...................6

Not working - other ..................... 7

Terminate if EMPLOYMENT ne 1, or 4 (can be working full or part time, or looking for work). 
MAIN QUESTIONNAIRE

\section{Section 1 Salary information}

\section{BASE: Show all respondents - informed consent}

You are invited to participate in a research study to better understand how Social Security benefits might affect retirement plans.

You were selected because you are a married worker who is likely to qualify for Social Security retirement and survivor benefits.

Things you should know:

This survey will first ask for information to estimate your Social Security benefits, then present you with estimated Social Security benefits and ask you about your retirement plans.

- The survey will take approximately 3 minutes to complete.

- Some of the information in the survey relates to benefits that a surviving spouse might receive from Social Security. This could make some people uncomfortable.

- You will receive credit from the GfK panel for completing this survey, and might improve your retirement preparedness as a side benefit.

- Participation is voluntary - you don't have to participate and can stop at any time.

- Your answers to the survey will be kept private and secure by GfK. Boston College researchers will not receive any information that can be traced back to you.

If you have questions about this research, you may contact Anek Belbase, anek.belbase@bc.edu, 6175526392.

If you have questions about your rights as a research participant, or wish to obtain information, ask questions, or discuss any concerns about the study with someone other than a researcher, please contact:

Boston College

Office for Research Protections

Phone: (617) 552-4778

Email: irb@bc.edu

Before agreeing to be part of the research, please be sure that you understand what the study is about. By clicking next, you are agreeing to be in this study. 
Q1 [S]

Have you worked for pay for at least 10 years?

1. Yes

2. No

Q2 [Number box, range: 1-100]

How old were you when you first started to work for pay?

[Number box]

\section{BASE: Show all respondents}

Q3 [Number box, range: 0-100,000,000]

Could you please give us an estimate of how much you were making on average per year over the past 5 years?

[Number box]

\section{BASE: Show all respondents}

Q4 [S]

Has your spouse worked for pay for more than 5 years?

1. Yes

2. No

\section{BASE: Show all respondents}

Q5 [S]

For most of her career, did your spouse:

1. work full time

2. work part time

3. was a full time homemaker

4. other [Please specify:] [Text box] 
Q6 [Number box, 0-100,000,000]

Could you please give us an estimate of how much your spouse was making, on average, per year over the past five years (or last five years of his/her career if retired)?

[Number box]

\section{Section 2: Intervention}

\section{BASE: all respondents}

Display_intervention [D]

The following section shows your estimated Social Security benefits based on your salary.

\section{BASE: $x$ group $=1$}

Display_group1 [D]

Estimated Benefit at Full

$\$ 2,723$ a month

View Estimated Benefits

Retirement age (67):

Where the link leads to a HTML page that look like the following:

\section{Your Estimated Benefits}

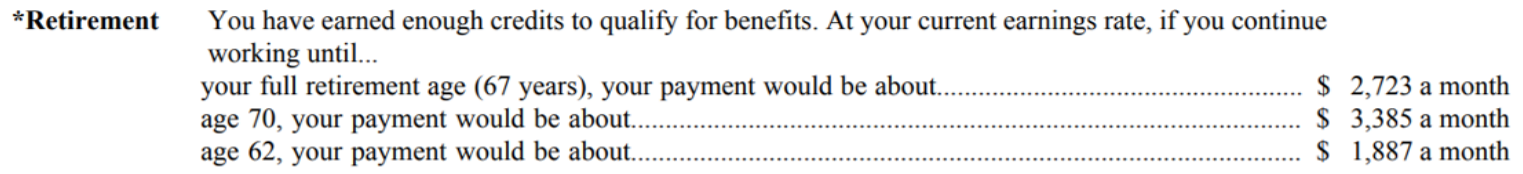

Please note that the benefits shown above are a rough estimate based on limited information about your workhistory. For a more precise estimate based on your full work history, please visit www.ssa.gov/myaccount/ 
BASE: $x g r o u p=2$

Display_group2 [D]

Estimated Benefit at Full

Retirement age (67):
$\$ 2,723$ a month

\section{View Estimated Benefits}

Followed by HTML page that shows:

Once you claim your Social Security benefit, you will receive monthly income from Social Security as long as you live. Your surviving spouse will also be entitled to a monthly benefit for life if he/she outlives you.

The benefits that your surviving spouse might receive as a widow are important to consider because, on average, women outlive men by 2.5 years, and 1 in 6 widows live in poverty.

The benefits you and your spouse are entitled to will depend on your claiming age:

\section{Estimated Social Security Benefits}

\begin{tabular}{|l|l|l|}
\hline Your claiming age & $\begin{array}{l}\text { Your monthly retirement } \\
\text { benefit amount }\end{array}$ & $\begin{array}{c}\text { Your surviving spouse's monthly } \\
\text { benefit as a widow/widower* }\end{array}$ \\
\hline $62-$ first eligible & & \\
\hline $66 / 67$ - full retirement age & & \\
\hline $70-$ latest claiming age & & \\
\hline
\end{tabular}

* If your surviving spouse has earned more than you over her lifetime, she will keep her own (higher) benefit as a widow.

Waiting to claim until your full retirement age of $<66 / 67>$ could help your spouse avoid poverty if she becomes widowed.

Please note that the benefits shown above are a rough estimate based on limited information about your work-history. For a more precise estimate based on your full work history, please visit www.ssa.gov/myaccount/ 


\section{BASE: $x g r o u p=3$}

\section{Display_group3 [D]}

Once you claim your Social Security benefit, you will receive monthly income from Social Security as long as you live. Your surviving spouse will also be entitled to a monthly benefit for life if he/she outlives you.

The benefits that your surviving spouse might receive as a widow are important to consider because, on average, women outlive men by 2.5 years, and 1 in 6 widows live in poverty.

The benefits you and your spouse are entitled to will depend on your claiming age:

\section{Estimated Social Security Benefits}

\begin{tabular}{|l|l|l|}
\hline Your claiming age & $\begin{array}{l}\text { Your monthly retirement } \\
\text { benefit amount }\end{array}$ & $\begin{array}{c}\text { Your surviving spouse's monthly } \\
\text { benefit as a widow/widower* }\end{array}$ \\
\hline $62-$ first eligible & & \\
\hline $66 / 67$ - full retirement age & & \\
\hline $70-$ latest claiming age & & \\
\hline
\end{tabular}

* If your surviving spouse has earned more than you over her lifetime, she will keep her own (higher) benefit as a widow.

Waiting to claim until your full retirement age of $<66 / 67>$ could help your spouse avoid poverty if she becomes widowed.

Please note that the benefits shown above are a rough estimate based on limited information about your work-history. For a more precise estimate based on your full work history, please visit www.ssa.gov/myaccount/

\section{Section 3: Post-intervention questions}

\section{BASE: Show all respondents}

Q7 [Number box, range from 62 to 70]

As you know, in the United States people can start claiming Social Security benefits between the ages of 62 and 70. At what age would you expect to start collecting these Social Security benefits?

[Number box] 
Q8 [S]

In planning when to retire, how important is the amount of monthly income you might get from Social Security?

1. Not important at all

2. Slightly important

3. Moderately important

4. Important

5. Very important

\section{BASE: Show all respondents}

Q9 [S]

Are you confident that your spouse will have enough in retirement if she becomes widowed?

1. Yes

2. No

3. Unsure

\section{BASE: $x g r o u p=1$}

Thank you for completing this survey. The purpose of this research is to find ways to help families understand how Social Security's survivor benefit could prevent poverty among widows. To that end, the information below provides more information about the prevalence of poverty among widows and how delaying when you claim Social Security could help.

Once you claim your Social Security benefit, you will receive monthly income from Social Security as long as you live. Your surviving spouse will also be entitled to a monthly benefit for life if he/she outlives you.

The benefits that your surviving spouse might receive as a widow are important to consider because, on average, women outlive men by 2.5 years, and 1 in 6 widows live in poverty.

The benefits you and your spouse are entitled to will depend on your claiming age:

\section{Estimated Social Security Benefits}

\begin{tabular}{|l|l|l|}
\hline Your claiming age & $\begin{array}{l}\text { Your monthly retirement } \\
\text { benefit amount }\end{array}$ & $\begin{array}{c}\text { Your surviving spouse's monthly } \\
\text { benefit as a widow/widower* }\end{array}$ \\
\hline 62 - first eligible & & \\
\hline $66 / 67-$ full retirement age & & \\
\hline $70-$ latest claiming age & & \\
\hline
\end{tabular}


* If your surviving spouse has earned more than you over her lifetime, she will keep her own (higher) benefit as a widow.

Please note that the benefits shown above are a rough estimate based on limited information about your work-history. For a more precise estimate based on your full work history, please visit www.ssa.gov/myaccount/

\section{STANDARD SCREENED OUT TEXT FOR PANEL SAMPLE:}

Use KP standard termination text.

END OF QUESTIONNAIRE 


\section{RECENT WORKING PAPERS FROM THE CENTER FOR RETIREMENT RESEARCH AT BOSTON COLLEGE}

How Does Delayed Retirement Affect Mortality and Health? Alice Zulkarnain and Matthew S. Rutledge, October 2018

How Have Automation and Trade Affected the Taxable Share of Covered Earnings? Gal Wettstein, Matthew S. Rutledge, and Wenliang Hou, October 2018

Spillovers from State and Local Pensions to Social Security: Do Benefits for Uncovered Workers Meet Federal Standards?

Laura D. Quinby, Jean-Pierre Aubry, and Alicia H. Munnell, September 2018

Accounting for Social Security Claiming Behavior

Svetlana Pashchenko and Ponpoje Porapakkarm, September 2018

The Minimum Wage and Annual Earnings Inequality

Gary V. Engelhardt and Patrick J. Purcell, August 2018

Exploring the Consequences of Discrimination and Health for Retirement by Race and Ethnicity: Results from the Health and Retirement Study

Ernest Gonzales, Yeonjung Jane Lee, William V. Padula, and Lindsey Subin Jung, July 2018

Financial Management Support for SSA Beneficiaries: Looking Beyond the Payee Annie Harper, May 2018

What Factors Explain the Decline in Widows' Poverty?

Alicia H. Munnell, Geoffrey T. Sanzenbacher, and Alice Zulkarnain, May 2018

Exploring the Rise of Mortgage Borrowing among Older Americans

J. Michael Collins, Erik Hembre, and Carly Urban, May 2018

How Might Earnings Patterns and Interactions Among Certain Provisions in OASDI Solvency Packages Affect Financing and Distributional Goals?

Melissa M. Favreault, March 2018

Distributional Effects of Alternative Strategies for Financing Long-Term Services and Supports and Assisting Family Caregivers

Melissa M. Favreault and Richard W. Johnson, March 2018

How to Pay for Social Security's Missing Trust Fund?

Alicia H. Munnell, Wenliang Hou, and Geoffrey T. Sanzenbacher, December 2017

All working papers are available on the Center for Retirement Research website

(http://crr.bc.edu) and can be requested by e-mail (crr@bc.edu) or phone (617-552-1762). 